\title{
EFFECT OF PROBLEM BASED LEARNING TO CRITICAL THINGKING SKILLS ELEMENTARY SCHOOL STUDENTS IN SOCIAL STUDIES
}

\author{
Rizki Pebriana ${ }^{1}$, Disman $^{2}$ \\ ${ }^{1}$ STKIP Siliwangi Bandung, Cimahi, Indonesia \\ ${ }^{2}$ University of Indonesia Education, Bandung, Indonesia \\ rizkipebriana117@gmail.com
}

\begin{abstract}
The main problem of this study is the lack of ability to think kriis Elementary School fifth grade students in the learning of Social Sciences. This study uses a quantitative approach with quasi experimental methods. The study population was the fifth grade elementary school students in District Ciparay Bandung regency. Sample consisted of 51 students divided into 25 students in the class $I V-A$ as an experimental group and 26 students in the class $I V-B$ as the control group. Instruments used comprises a written test regarding social issues. Quantitative analysis is performed against the average pretest and posttest critical thinking skills by using the t test and Mann Whitney test. The results showed that the differences are critical thinking skills in students using problem-based learning model at initial measurement (pre-test) and the final measurement (post-test). encourage the student can solve his problems with critical thinking, there are no differences in the ability of critical thinking in students who use conventional learning model at initial measurement (pre-test) and the final measurement (posttest), there is an increased critical thinking skills in students whose learning using model-based the problem is higher than students whose learning using conventional learning.
\end{abstract}

\section{Keywords: Problem Based Learning, Critical Thinking, Social Studies}

\section{INTRODUCTION}

The quality of education is now a concern. Quality education is an effort to be able to take part in the era of globalization and dealing with the challenges of the future. Education is required to be relevant to the ever-evolving needs of society due to the advancement of science and technology (future-oriented education). Through education is expected to form a complete Indonesian human so that the current and future problems can be overcome. This is in line with Kunandar (2007, pp. 10) "education is the key to modernization or education is the investment of human beings to gain recognition among experts".

The process of education can't be separated from the learning process, where learning is essentially a process of interaction that is mutual between teachers with students or vice versa between students with teachers and students with other students. In the process of learning, social science is one of the lessons that become compulsory teaching materials in schools in this case, especially in elementary school. The objectives of this course as stated in the KTSP Primary School curriculum (2006, pp. 575) are as follows:

1. Know the concepts related to the life of society and its environment.

2. Have basic skills for logical and critical thinking, curiosity, inquiry, problem solving, and skills in social life. 
3. Have a commitment and awareness of social values and humanity.

4. Have the ability to communicate, work together and compete in a pluralistic society, locally, nationally and globally.

The subject of the study of social learning is about relationships between people. This is in accordance with the KTSP curriculum (2006, p.575) which implies that the scope of social subjects are:

1. Man, Place and Environment

2. Time, Sustainability and Action

3. Social and Cultural System

4. Economic Behavior and Welfare

Furthermore, one of the social goals in the school is to prepare the child to have skills, this is in line with Sapriya's opinion $(2008$, p.12) thatSocial education aims to prepare learners as knowledge-abusers, skills, attitudes and values that can be used as the ability to solve personal problems or social problems and decision-making skills and participate in various community activities in order to become a good citizen.

In social learning there are social skills that can be taught and trained starting from the level of early childhood and elementary. Social skills that need to be developed in today's social learning are critical thinking skills, technological skills, self-control skills, job-taking skills, problem-solving skills, cooperative skills, money use skills and decision-making skills. The expositions are in line with those proposed by Supriatna et al (2009, p. 53), namely that skills that must be formulated in the school is the ability to obtain information, communicate, selfcontrol, cooperation, using numbers, solve problems and skills in making decisions.

One of the skills that must be mastered by elementary school age children is social skills. Because basically humans need other people to carry out life that we often call that human being a social creature. Therefore, to socialize with others, people must have social skills, how to communicate, cooperate, creativity, and become a good citizen are some social skills that must be mastered so that in our society life can be received well.

Social skills should be of particular concern starting from elementary school because today there are many social problems that occur in elementary school age such as mutual mockery among friends, happened between students, school children who fled from home and lack of concern for the importance of saving students. social skills developed in the United States through Association for Supervision and Curriculum Development (ASCD) has developed a formulation of skills that learners must possess such as thinking and reasoning skills, working skills with others, self-control skills, and skills in exploiting job opportunities, 
from these skills there are specific formulations related to social skills such as conflict-solving skills, working with multiple groups, taking and considering life risks, using information, money use skills effectively and using basic skills in order to live together with the community (Supriatna, TT). In addition, in the era of globalization as now required social skills that must be mastered from an early age in order to compete in this era of globalization in the $21 \mathrm{st}$ century. There are some social skills children must have to face globalization in the 21 st century according to Griffin (2012, pp. 8) said that creativity And Innovation; Critical Thinking, Problem Solving, And Decision Making; Learning To Learn, Metacognition; Communication; Collaboration, Teamwork; Information Literacy; ICT Literacy; Elaboration Of Key Concepts Of Ict Literacy Based On Ets Framework; Citizenship, Local And Global; Life And Career; Personal And Social Responsibility.

As a statement from Griffin above that is to face the era of globalization in the 21 st century critical thinking skills must be owned by students. In an attempt to solve problems in everyday life, one's ability to think is a very powerful ability to determine the person's success in the face of globalization in the 21 st century. Critical thinking skills are one of the highestorder thinking skills. According to Ennis in Fisher (2009, p.4) critical thinking is a sensible and reflective thinking that focuses on deciding what to believe or do. Meanwhile, according to John Dewey in Fisher (2009, p.2) defines critical thinking as a persistent, and conscientious process of an assumption.

In primary school learning should be developed thinking ability, especially critical thinking skills. The materials and stages of critical thinking skills developed in primary schools are simplified and adapted to the cognitive and learner levels of primary school students who are still at concrete operational stage (Yaumi, 2012).

If the critical thinking skills have been trained in primary school, the benefits will be felt by the learners when they are in higher education level. If the students' skills in problem solving and decision-making have been trained in elementary school level then students will be better prepared and able cognitively when given more complex problems at higher education levels. This is in line with the opinion of Lapono, et al (2010) that individual success in mastering the basics of thinking skills at the stage of development of middle childhood influences on the developmental stage of a dole scene. This means that individual academic success at higher levels of education is largely determined by its success in academic activities or learning at the elementary level of education.

One of the efforts that can be done is the learning process conducted in elementary school especially in Social Studies subjects in class IV on the material "Social Problems" with 
learning that gives more emphasis such as giving a real example, involving students to participate in providing feedback sopi solution that will make students more easily understand the material and can apply in everyday life in the home, school and community. Learning model that is considered to improve social skills especially critical thinking skills is a problem-based learning model, for that in this study will try to model the problem-based learning model to find out how its influence on improving critical thinking skills. This is reinforced by the opinion of Biggs (1991) which insists that: Certain pedagogical strategies, such as problem-based learning, develop hypotheses, seek required knowledge, apply solutions to problems, and evaluate the outcome of the decision and the process of learning. This means that certain pedagogical strategies, such as learning-based issues, can provide a context for students to systematically interpret problems, develop hypotheses, find needed information, apply solutions to problems, and evaluate decision outcomes and learning processes.

Problem Based Learning (PBL) is a learning model that uses real problems as a context for learners to learn about critical thinking and problem-solving skills (Sudarman, 2007). Problem-Based Learning is a strategy that begins by exposing students to real-life problems (authentic) or simulated problems, so students are required to think critically and place students as a problem solver so that they are expected to become skilled in critical thinking and problem solving. Furthermore, Sanjaya (2006) states that problem-based learning can be defined as a series of learning activities that emphasize the process of solving problems faced scientifically. While Ward, 2002; Stepien, et al., 1993 (in Sutrisno, 2007) states that the problem-based learning model is a learning model involving students to solve a problem through the stages of scientific method so that students can learn the knowledge related to the problem and also have the skills to solve problem.

Based on the above explanation it is clear that problem-based learning is important to implement in order to improve the mastery of social concepts and to improve the ability to solve social problems of elementary school students. Therefore, the authors are interested to conduct research with the title "Effect Of Model-Based Learning Problems To Think Of Critical Skills Elementary School Students In Social Studies”.

\section{METHODS}

This study uses quasi-experimental method with quantitative approach. The research was conducted on the students at SD Gadis, Ciparay Bandung. The result of data collection was obtained through test, observation, and interview. 


\section{RESULTS AND DISCUSSION}

The pretest of critical thinking skills is derived from the tests given before the learning is applied in the experimental class and control class. Analysis of equality score test score gain ability critical thinking between students in experimental class and experimental class aims to show that there is an increase or not. Before performing the two-averaging test, firstly test the normality and homogeneity of variance. The steps of testing this hypothesis are as follows:

\section{Analysis of Gain Data Score Critical Thinking Skills of Students in Classroom Experiment and Control Class}

The sample size of the two classes is 26 students for the experimental class and 25 students for the control class. On average the gain scores of the critical thinking skills of the experimental students had an average gain value of 0.50 and higher than the average gain of the control class having only a mean value of 0.03 . The average disjunction between the two classes is 0.47 . The maximum gain score in the control class is 1.00 , while the maximum gain score in the experimental class is 0.93 . The minimum gain score in the control class is -1.31 , while the minimum gain score in the experimental class is 0.15 . The difference in gain scores between the experimental and control classes is moderate, so both classes have a relatively different score of students' critical thinking skills. Data processing scores the ability to test this mathematical conjecture begins by doing the normality test in the experimental class and control class. Test normality score gain ability of critical thinking siswakedua class using Kolmogorov-Smirnov test in order to know whether the data from each sample was normal distribution or no. Test this normality using the help of software SPSS 23.0 for windows.

\section{Test Normality Data Score Gain Ability Critical Thinking Students in Experimental Class}

There is also a form of hypothesis test of normality of gain scores the ability to test mathematical

Conjecture of experimental class students:

H0: Score gain ability of critical thinking of Student experimental class normal distribution.

H1: Score gain ability critical thinking of Student experimental class is not normally distributed.

The criterion used to reject and accept $\mathrm{H} 0$ based on $\mathrm{P}$-value is $\mathrm{H} 0$ is rejected if the value of significance P-value $<\alpha$ (significance level 0.05 ) and H0 is accepted if the value of significance P-value $\geq \alpha$. From the calculation results using software SPSS 23.0 for windows.

Score gain of critical thinking ability of experimental class students for Kol mogor ofSmirnov normality test has $\mathrm{P}$-value $(\mathrm{Sig})=0,057>0.05$ so that $\mathrm{H} 0$ is accepted at significance 
level $=0.05$. That is, the gain scores the ability to test the mathematical conjecture of the experimental class is normally distributed.

\section{Test Normality Data Score Gain Ability Critical Thinking Students in Class Control}

There is also a form of hypothesis test normality score gain ability test mathematics conjecture students control classes:

H0: Score gains students' critical thinking ability of normal control class.

H1: Score gains students' critical thinking ability of control class is not normally distributed.

The criterion used to reject and accept $\mathrm{H} 0$ based on $\mathrm{P}$-value is $\mathrm{H} 0$ is rejected if the value of significance P-value $<\alpha$ (significance level 0.05) and H0 is accepted if the value of significance P-value $\geq \alpha$. From the calculation results using software SPSS 23.0 for windows.

The gain score is the ability to test mathematical conjectures of control-class students. There is also test result of normality of score gain ability of critical thinking thinking of control class student for Kolmogorof-Smirnov normality test has score P-value (Sig) $=0,00<0.05$ such that $\mathrm{H} 0$ is rejected at significance level $=0.05$. That is, the score gain ability of critical thinking of student control class this distribution is not normal.

Based on the results of the Kolmogorof-Smirnov normality test the experimental class has a gain score of students' critical thinking thinking ability to normally distributed, while the control class has a gain score of critical thinking ability that is not normally distributed. So that data processing can be continued with non parametric test Mann Whitney.

\section{Test of Two-Point Differences Gain Score Data for Student's Critical Thinking Skills}

In this study because both classes have a gain score of critical thinking ability of students who are not abnormally distributed, then on test the average difference using non parametric test of mann-Whitney with significance level $\alpha=0,05$ which done by using program of SPSS 23.0 for windows. There is also a hypothesis that is used follows:

- H0: There is no difference score gain critical thinking ability of experiment class and control class.

- H1: There is a significant difference in the gain scores of students' critical thinking skills and control class.

- $\mathrm{H} 0$ is rejected if the value of significance $\mathrm{P}$-value $<\alpha$ (significance level). H0 is accepted if the significance value of $\mathrm{P}$-value $\geq \alpha$ (significance level).

Result of Mann Whitney difference of average gain of critical thinking ability of experiment class and control class with significance level $\alpha=0,05$ with P-value score (Sig. 2 
tailed) $=0,000$ at significance level $\alpha=0,05$ because one tested direction so 0.000 divided by 2 results $=0,000<0,05=\alpha$, such condition $\mathrm{H} 0$ rejected, there is a significant difference score gain ability thinking criticism experimental class and control class.

\section{A. DISCUSSION}

To see the improvement of the ability of critical thinking in students whose learning using Problem Based Learning model is higher than students whose learning using conventional learning will be $\mathrm{t}$ test, but first test of normality and homogeneity test.

On average the gain scores of the critical thinking skills of the experimental students had an average gain value of 0.50 and higher than the average gain of the control class having only a mean value of 0.03 . The average disjunction between the two classes is 0.47 . Maximum gain score in the control class is 1.00 , while the maximum gain score in the experimental class is 0.93 .

The result of normality test of data gain critical thinking ability in experiment class get significance value equal to 0,057 , because the value is bigger than $\alpha=0,05$, such that $\mathrm{H} 0$ is accepted at significance level $=0.05$. That is, the gain scores of critical thinking skills of these experimental colleagues are normally distributed. While the control class get a significance value of 0.000 because the value is smaller than $\alpha=0.05$, such that $\mathrm{H} 0$ is rejected at the level of significance $=0.05$. That is, the score gain ability of critical thinking of Students this experiment is not normal.

Based on the results of the Kolmogorof-Smirnov normality test the experimental class has a gain score of students' critical thinking thinking ability to normally distributed, while the control class has a gain score of critical thinking ability that is not normally distributed. So that data processing can be continued with nonparametric test Mann Whitney.

The result of difference test of average gain of critical thinking ability of experimental class and control class students get a significance value of 0.000 . Since the value is smaller than $\alpha=0.05$, then $\mathrm{H} 0$ is rejected. That is, the average gain of the experimental class is higher than the average gain of the control class. It can be concluded that the improvement of critical thinking ability in students whose learning using problem-based learning model is higher than students whose learning using conventional learning.

Improved critical thinking skills in students whose learning using problem-based learning model is higher than students whose learning uses conventional learning. This is because according to Dutch (Amir, 2009, pp. 21) Problem Based Learning is an interactional method that defies students to learn to study, working together in groups to find solutions to real problems, the problem is used to remind curiosity and ability analytical and initiative on 
the subject matter. Problem-Based Learning prepares students to think critically and analytically to seek and use appropriate learning resources.

In addition, Problem-Based Learning has more, among others, according to Sanjaya (2006, pp. 88):

a. Students better understand the concepts taught because they themselves find the concept. Roh (2003) mentions that the effectiveness of the PBL depends on the characteristics of the students and the classroom culture, as well as the tasks (problems) given. PBL supporters believe that when students develop methods or ways to construct their own procedures, they are integrating their conceptual knowledge with their procedural skills.

b. Involves actively solving problems and demanding higher student thinking skills.

c. Knowledge is embedded in the students' schema so that learning is more meaningful. Hmelo-Silver, Chernoblisky, and DaCosta (2004) also state that students who learn knowledge in the context of problem-solving such as PBL are likely to recall and transfer their knowledge to new problems.

d. Students can feel the benefits of learning because the problems that are solved are related to real life.

e. The learning process through problem-based learning can familiarize students in dealing with and solving problems skillfully. When faced with problems in everyday life students have the ability to solve them

f. Can develop students' ability to think critically and develop their ability to adapt to new knowledge.

\section{CONCLUSION AND RECOMMENDATIONS CONCLUSION}

Based on the formulation of problem analysis results and discussion of the results of research as described in this study, then obtained the following conclusions:

1. here is a difference in the ability of critical thinking in students using problem-based learning model on pretest and final measurement (posttest). This is caused in Problem Based Learning students directed to formulate problems, analyze problems, formulate hypotheses, collect data, testing hypotheses, and formulate recommendations solving problems that encourage students to solve problems faced with critical thinking.

2. There is no difference in the ability of critical thinking in students using conventional learning model on pretest and final measurement (posttest). This is because the conventional learning model does not attempt to apply methods and the use of factual 
media and learning resources. In addition, in the conventional learning model is not based on the problem and does not provide opportunities for students to solve the problem itself.

3. There is an increase in critical thinking skills in students whose learning uses a problembased learning model is higher than students whose learning uses conventional learning. It can be concluded that the improvement of critical thinking ability in students whose learning using problem-based learning model is higher than students whose learning using conventional learning. This is because Problem-Based Learning is a strategy that begins by confronting students on real-life issues (authentic) or simulated problems, so students are required to think critically and place students as problem solver so that students become skilled in critical thinking.

\section{RECOMMENDATION}

Based on the research conclusions described earlier, the implications and recommendations in this study are

1. Learning by using Learning-Based Model Problems can be used as an alternative learning in elementary school in an effort to develop students' critical thinking skills. However, in applying this learning need to pay attention to the learning steps so that the implementation of learning can be done well. Implementation of learning will be done well if supported by the media learning and teacher in teaching. Therefore prepare well and mature so that students can get actively involved in learning. In addition, teachers also need to keep the classroom conditions to stay good, so that all students can follow the learning well.

2. Research with Learning Model-Based Learning This problem is done very limited nature both the subject of research and subject. The population of this study is only students of SDN in Ciparay sub-district of Bandung Regency and the samples are taken only two classes so that the research results are not necessarily according to the school or other areas that have different characteristics and student population. It is hoped that the next researcher will be able to do research with a wider population with the class being sampled more with the aim of minimizing errors and getting more accurate results.

3. The subject discussed only for two subjects that is about the problems in the environment. Therefore, it is suggested to the next researcher to be able to continue the research on other subject.

4. Need to be considered by teachers who want to use Learning-Based Model Problems that this kind of learning requires a relatively long time because students should be given the opportunity to think and convey ideas and ideas to analyze the material being studied. 
Therefore, the instructional material should be prepared to pay attention to aspects of effectiveness.

5. Learning with Learning-Based Models This problem in addition to improving students' critical thinking can also be done other research to see the effect of learning with LearningBased Model Problems to other abilities.

\section{REFERENCES}

Biggs J.B. (1991) Approaches to learning in secondary and tertiary students in Hong Kong: some comparative studies. Educational Research Journal 6, 27-39.

Fisher, A. (2009). Berpikir kritis sebuah penghantar. Jakarta: Erlangga.

Griffin, P. (2012). Assessment and teaching of 21st century skills. New York: Springer.

Kunandar (2007). Guru profesional. Jakarta: Rajawali Pers.

Lapono, N., dkk. (2010). Belajardanpembelajaran SD 2 sks. Jakarta: DirektoratJenderalPendidikanTinggi.

Sanjaya, W. (2006). Strategi pembelajaran. Jakarta: Kencana Prenada Media Group Sapriya. (2008). Pendidikan IPS. Bandung: Yasindo Multi Aspek.

Sudarman. (2007). Problem based learniing: model pembelajaran untuk mengembangkan dan meningkatkan kemampuan memecahkan masalah. Jurnal Pendidikan Inovatif. 2 (2): $68-73$.

Supriatna, N, dkk. (2009). Pendidikan IPS SD. Bandung: UPI Press

Supriatna, N. (TT). bahan belajar mandiri pendidikan IPS SD. Tersedia: http://file.upi.edu/Direktori/DUAL-MODES/PENDIDIKAN IPS DI SD BBM 2.pdf.

Sutrisno. (2007). Pembelajaran Berbasis Masalah. [Online]. (Tersedia): (http://lubisgrafura.wordpress.com).

Yaumi, M. (2012). Pembelajaran berbasis multiple intelligences. Jakarta: Dian Rakyat. 